\title{
Profitability and Resource Use Efficiency in Cassava Production: Evidence from Delta State, Nigeria
}

\author{
Theophilus Miebi Gbigbi ${ }^{1}$, V.A.A. Chuks-Okonta ${ }^{2}$ \\ 1,2 Department of Agricultural Economics and Extension, Delta State University Asaba Campus, PMB 95074, \\ Asaba, Nigeria \\ Corresponding Author: Theophilus Miebi Gbigbi
}

\section{ABSTRACT}

Cassava has played and continues to play an outstanding role. The country's failure to meet current demand has been due to the efficiency of farmers' use of resources. The study examined resource use efficiency in cassava production. Data from 120 cassava producers were carefully chosen using random sampling procedure. Descriptive statistics and multiple regression model were applied to analyze the data. The results disclosed that the greater part of the growers were female with mean age of 45 years, educated and married. The mean household size was 6 persons with mean farming experience of 16 years. Majority of the producers belong to farming association. The result of cost and returns shows that the total production cost, total revenue realized and profit were $\$ 221,500$, $\$ 398,000$ and $\$ 176,500$ respectively with BCR of 1.80 which implies that cassava production is profitable. The regression estimated showed that farm sizes, fertilizers, labour and planting material influence the output produced. The estimated output elasticity was 0.934 , which means decreasing return to scale. The result indicated that farm size, fertilizers, labour and planting materials were inefficiently used, thereby dropping below the best economic level. The low ratios of MVP / MFC of the entire variables were shown to be less than unitary. Approximately 56.19\%, 99.98\%, 97.67\%, 99.99\% and $11.28 \%$ increase in MVP are necessary to optimize the allocation of farm size, fertilizer, labour, planting material and agrochemical. Major problems include inaccessibility to financial services, high labour cost, poor market prices and insufficient extension services. Agricultural policies should be aimed at supplying agricultural inputs, such
\end{abstract}

as fertilizer and effective extension programs to guarantee the productive usage of resources. It is also suggested that extension facilities be intensified to provide farmers with information on new innovations and methods of farming while steps should be taken to lessen the militating effect of the constraints.

Keywords: Resource Use Efficiency, Cassava Production, Benefit-Cost Analysis, Farmers.

\section{INTRODUCTION}

In many tropical African countries, Cassava is an indispensable food, particularly in Nigeria, where it plays a leading role in the food economy (Agwu and Anyaeche, 2007). According to Makinde et al. (2015), Nigeria is the world's leading producer of cassava and ranks 2 nd after yam in terms of root and tuber cultivations with economic values of about 54.0 million metric tons in Nigeria. The crop has continuously played important roles, including a major income source for agriculture, a low cost food source for family food security, and jobs for rural households in Nigeria. Cassava is a staple crop with intrinsic features which attracts smallholder farmers to its cultivation. These features include the ability to grow in soils where other crops have not succeeded (Obayelu et al., 2013). The crop can withstand stresses like drought, available throughout the year, cheap to grow and generate good income for farmers, which provides household food security. However, approximately 90 percent of cassava 
produced in the country Nigeria is locally eaten as food (Udemezue, 2019).

Cassava is traditionally consumed by processing the fresh roots into Garri, fufu, lafun, tapioca, flour, kpokpo garri and starch (Wasiu et al., 2017). This crop has achieved an export status due to increasing demand for it as manufacturing raw material, and since 2009, Cassava production has been increasing, possibly due to this intervention. However, Nigeria has an estimated average low yield of $14.7 \mathrm{mt} /$ ha (Nang'ayo et al., 2007) compared to $19 \mathrm{mt} /$ ha in Indonesia, a tropical nation where production is similarly limited by low input, high commodity price variability, and the lack of sufficient infrastructure (Sugino and Mayrowani, 2009). Moreover, the cassava farms are characterized by low productivity, just similar to the other crops, which is a key problem in the nation's agriculture. Nigeria also needs to copiously harness the economic value of cassava to increase the Gross Domestic Product (GDP) to a higher ranking next to crude oil. There is widespread awareness that farmers will increase the level of agricultural production based on the existing resource capacity and technology which improves their productivity (Udoh and Etim, 2008). This explanation therefore represents a key reason why the notion of agricultural efficiency remains an important economic study in Nigeria, with scarce resources where adoption of better technologies are being reduced. In order to achieve this, the efficiency and profit margins of the producers must be enhanced.

Efficiency analysis in agriculture typically includes the ability for farms to generate a certain amount of output at least cost from a given resources or a certain amount of yield (Girei et al., 2013; Tambo and Theresa, 2010). Efficiency described the performance of the procedures used to transform inputs into output. This infers that the quantity of existing resources have to be used efficiently to achieve the optimum level of production. However, the allocative efficiency analysis seeks to optimize the objective function of profit maximization subject to resource constraint. Resources are said to be allocated efficiently where the value of each resource's marginal product is equal to its price. Agricultural productivity knowledge and policies are needed to know the resources whose quantity or rates of use are to be increased or decreased for successful results (Alimi, 2000). Thus, the focus is currently on small-scale farmers' cassava production, which dominated the farming population in Nigeria to enhance resource efficiency (Abdulkadir and Umar, 2015; Goni et al., 2013). Given existing resources and available technology, the scope of cassava production can be enriched and sustained by the efficient usage of resources (Udoh, 2005). There is therefore a call for an appraisal of efficiency level cassava producers. Despite attempts by different governments to increase efficiencies status of the producers who are the key players in the production, this initiative however, could not achieve the desired targets due to the challenges distressing the utilization of production technologies.

Understanding the production elasticity, efficiency and socio-economic features of farmers that influence this efficiency would contribute to improve agricultural policies and schemes which in turn could contribute to the intensification of food production (Mango et al., 2015). The present level of resources usage needs to be analyzed, so that the factors responsible for the output level can be identified to further enhance production. To the best of our understanding studies that examine the resource use efficiency and their determinants is lacking. This study tend to address this serious lacuna. The findings of this study would greatly benefit farmers and other stakeholders in the agricultural sector, as they will help to highlight the variables that would better expand the efficiency of the producers. The findings will also guide policymakers in formulating policies to enhance the welfare of the growers, so that cassava production 
can be increased. This will also provide government-relevant data to resolve cassava issues.

\section{MATERIALS AND METHODS}

The research was carried out in Ika South Delta State. It has a land area of $436 \mathrm{~km} 2$ and a populace of 162,594 (NPC, 2006). The tropical climate is marked by dry and rainy seasons. The rainy season starts in April and finishes in October. August and September are the wettest months. The dry season begins in November and finishes in April. Yam, cassava, melon, tomatoes and plantains are among the major crops grown in the area.

Primary data were collected using questionnaires. A multiple stage selection procedure was used. Firstly, eight communities were carefully chosen from the LGA. The next stage of the sampling involved the random selection of 15 farmers from each of the chosen communities in the LGA to give an aggregate of 120 farmers. However, three questionnaires were rejected due to insufficient information. Hence, 117 respondents were used for the research. Descriptive statistics and inferential statistics were utilized for analysis of data.

\section{Model Specification Regression model}

Regression model was applied to examine input-output relationship and the implicit form is specified as:

$\mathrm{Y}=\mathrm{f}\left(\mathrm{X}_{1}, \mathrm{X}_{2}, \mathrm{X}_{3}, \mathrm{X}_{4}, \mathrm{X}_{5}\right.$

$\mathrm{Y}=\mathrm{a}_{0}+\mathrm{a}_{1} \mathrm{X}_{1}+\mathrm{a}_{2} \mathrm{X}_{2}+\mathrm{a}_{3} \mathrm{X}_{3}+\mathrm{a}_{4} \mathrm{X}_{4}+\mathrm{a}_{5} \mathrm{X}_{5}+$ $\mathrm{Xn}+\mathrm{e} \quad$ (2)

Where,

$\mathrm{Y}=$ output of cassava (tonnes)

$\mathrm{X}_{1}=$ farm size (ha)

$\mathrm{X}_{2}=$ labour used in mandays

$\mathrm{X}_{3}=$ fertilizer used $(\mathrm{kg})$

$\mathrm{X}_{4}=$ cassava cuttings $(\mathrm{kg})$

$\mathrm{X}_{5}=$ herbicide used (liter)

$\mathrm{e}=$ stochastic error term

$\mathrm{a}_{1}-\mathrm{a}_{5}=$ parameters estimate

$\mathrm{a}_{0}=$ constant

\section{Efficiency Ratio:}

Efficiency ratio was used to determine the resource use efficiency of the farmers. The estimated coefficient of the relevant independent variables were applied to compute the marginal factor costs (MFC).

$\mathbf{r}=\frac{\text { MVP }}{\text { MFC }}$

The equation is

Where $r=$ Efficiency ratio

MVP Marginal value product of variable inputs

MFC $=$ Marginal factor cost

The MVP was estimated by means of the regression coefficient for each input and as well the output as shown.

\section{MVPx $=$ bx x py}

Where

Py $=$ Price per unit of output

$\mathrm{bi}=$ Regression co-efficient of input $\mathrm{i}(\mathrm{i}=$ $1,2 \ldots \ldots \ldots \ldots . . n)$

mvpxi $=$ marginal value product of input xi The prevailing market price of inputs was used as the marginal factor cost (MFC).

The values of the ratios are construed thus, If $\mathrm{r}<1$, implies overutilization. Consequently, if the amount input is intensified profit will increase, If $r$ $>1$, it denotes underutilization. If the amount input is reduced, profit will rise.

If $r=1$, it suggests that inputs are optimally utilized.

\section{Marginal Value Product (MVP) Adjustment}

Estimation of the percentage variation in MVP for each input is necessary to optimally utilize the inputs, which means $\mathrm{r}=1$ or $\mathrm{MVP}=\mathrm{MFC}$, and was computed by the equation:

$\mathrm{D}=\left(1-\frac{M F C}{M V P}\right) * 100$

Where,

$\mathrm{D}=$ percentage variation in MVP for each resource.

\section{Model for Gross Margin}

margin as:

Gbigbi (2019) expressed gross

$\mathrm{NFI}=\mathrm{TR}-\mathrm{TC}$

$\mathrm{GM}=\mathrm{TR}-\mathrm{TVC}$ 
Gross margin $=$ total revenue - total variable cost

$\mathrm{TR}=$ Total revenue

TVC $=$ Total variable cost

$\mathrm{NFI}=\mathrm{Net}$ farm income

\section{RESULTS AND DISCUSSION}

\section{Socioeconomic features of the producers}

The results of sex indicate that $67.5 \%$ of the producers were female while $32.5 \%$ of them are male. This demonstrated that more female farmers participated in cassava production. The result agrees with Adebisi et al. (2012) female farmers dominated arable crop farming in southwestern Nigeria. The result discovered that farmers age ranges between 26-70 years as in Table 1. Larger parts of the producers were between the ages of 35-43years which accounts for $34 \%$ with a mean age 45 years. This implies that the producers are young and active to improve production. This supports the finding of Gbigbi (2021) in Delta State.

Research shows that $23.1 \%$ of the producers were single, $62.4 \%$ were married while $6.0 \%$ were divorced and $8.5 \%$ were widows. This suggests that one's married are more engaged arable crop farming. The implication is that marriage remains a valued culture that activate production. The high proportion of marriage respondents $(62.4 \%)$ shows that they derive enough income in cassava production to support their families (Ebewore et al., 2013). About $21.4 \%$ of the producers had primary education, while $38.5 \%$ of them had secondary education. Only $21.4 \%$ had no education while $18.8 \%$ had tertiary education. This means that a sufficient number of producers will be enthusiastic to achieve an upsurge in productivity by the use of better technologies. The standard of labour is enhanced by education and the adoption of emerging technology is thus increased (Eze and Nwibo, 2014). Cassava farmers could thus easily implement new technologies that could increase their productivity level. The result indicates that $54.7 \%$ had household size between 1-5 persons, (30.8\%) had 6-10 people and $11.9 \%$ had $11-15$ people. The average family size was 6 persons. This result implies that cassava farmers had access to family labour for cassava production. The consequence is that availability of farm labour, farm size and output is influenced by household size (Amaza et al., 2009). On the other hand, large household size is associated with increased household consumption expenditure, which reduces the money that is for production purposes.

The result shows that $34.2 \%$ of the growers had between 1-9 years' experience in farming, $36.7 \%$ had between $10-18$ years' experience, $15.4 \%$ had between 19-27 years' experience, and (13.7\%) had between 28-44 years farming experience. The average farming experience was 16 years. Farming experience performs a dynamic role in agricultural production. It is expected that the higher the farmers experience, the better will be the production capacity of producers (Adeyemo et al., 2010). Productivity increases with experience in farming as farmers master the technique of cassava production to avoid previous mistakes (Audu et al., 2013). Farming experience determines the production status of the producers as it enables them to select the right crop varieties for the management of the farms and practices that are suitable to the environment (Salau et al., 2010). Years spent in farming by a farmer determine his ability to make effective farm management decisions as regard to input combination. The result shows that $81.2 \%$ of the producers belong a cooperative society while $18.8 \%$ were non-members. According to Gbigbi (2017), being a member of farming association would enable the farmer have easy access to timely funds and materials needed for production and accessibility to information on improved technologies and markets for farm produce. Members of farming association can also enhance the accessibility of farmers to credit sources and serve as a medium for sharing of ideas that can improve farm activities (Oyewole, 2012). 
Table 1. Socio-Economic Features of Respondents ( $n=117)$

\begin{tabular}{|c|c|c|c|}
\hline Variable & Frequency & Percentage & Mode/Mean \\
\hline \multicolumn{4}{|l|}{ Sex: } \\
\hline Male & 38 & 32.5 & \\
\hline Female & 79 & 67.5 & Female \\
\hline \multicolumn{4}{|l|}{ Age (Years) } \\
\hline $26-34$ & 16 & 13.7 & \\
\hline $35-43$ & 40 & 34.2 & \\
\hline $44-52$ & 34 & 29.0 & 45 years \\
\hline $53-61$ & 17 & 14.6 & \\
\hline $62-70$ & 10 & 8.5 & \\
\hline \multicolumn{4}{|l|}{ Marital Status: } \\
\hline Single & 27 & 23.1 & \\
\hline Married & 73 & 62.4 & Married \\
\hline Divorced & 7 & 6.0 & \\
\hline Widow & 10 & 8.5 & \\
\hline \multicolumn{4}{|l|}{ Education } \\
\hline $\begin{array}{l}\text { No formal } \\
\text { education }\end{array}$ & 25 & 21.4 & \\
\hline $\begin{array}{l}\text { Primary } \\
\text { education }\end{array}$ & 25 & 21.4 & \\
\hline $\begin{array}{l}\text { Secondary } \\
\text { education }\end{array}$ & 45 & 38.5 & Secondary \\
\hline $\begin{array}{l}\text { Tertiary } \\
\text { education }\end{array}$ & 22 & 18.8 & \\
\hline \multicolumn{4}{|l|}{ Household size } \\
\hline $1-5$ & 64 & 54.7 & \\
\hline $6-10$ & 36 & 30.8 & 6 persons \\
\hline $11-15$ & 14 & 11.9 & \\
\hline $16-20$ & 3 & 2.6 & \\
\hline \multicolumn{4}{|c|}{ Farming Experience: } \\
\hline $1-9$ & 40 & 34.2 & \\
\hline $10-18$ & 43 & 36.7 & 16 years \\
\hline $19-27$ & 18 & 15.4 & \\
\hline $28-27$ & 16 & 13.7 & \\
\hline \multicolumn{4}{|c|}{ Member of farming association } \\
\hline No & 22 & 18.8 & \\
\hline Yes & 95 & 81.2 & Yes \\
\hline
\end{tabular}

\section{Cost and Returns of Cassava Production}

Table 2. Cost and return analysis of cassava production

\begin{tabular}{|l|l|l|}
\hline Cost/Return Items & $\begin{array}{l}\text { Cost/Value } \\
\text { (N/ha) }\end{array}$ & $\begin{array}{l}\text { Percentage } \\
(\%)\end{array}$ \\
\hline $\begin{array}{l}\text { A. Variable Cost } \\
\text { Stem cutting (N) }\end{array}$ & 24000.00 & 10.8 \\
Fertilizer (kg) & 21000.00 & 9.5 \\
Labour (man-day/N) & 108000.00 & 48.8 \\
Agro-chemical (litre) & 7500.00 & 3.4 \\
Transportation & 35000.00 & 15.8 \\
Total variable cost & $195,500.00$ & 88.3 \\
\hline B. Fixed Cost of farm & 6000.00 & 2.7 \\
$\begin{array}{l}\text { Depreciation } \\
\text { tools(knap sprayer, hoe and } \\
\text { cutlass }\end{array}$ & & \\
Depreciation on land & $20,000.00$ & 9.0 \\
Total fixed cost & 26000.00 & 11.7 \\
\hline C. Total Cost & $221,500.00$ & \\
\hline Revenue & & \\
Total revenue (N) & $398,000.00$ & \\
Net farm income (NFI) & $176,500.00$ & \\
Gross margin (GM) & $202,500.00$ & \\
\hline Benefit cost ratio (BCR) & 1.80 & \\
\hline
\end{tabular}

Findings indicate that variable cost items constitute the bulk (88.3\%) of the total cost of production (Table 2.). Therefore, they are very crucial to the success in smallholder farmers' production level.
Similarly, labour accounted for about $48.8 \%$ of total production outlay and is therefore, important in the determination of the attainment of the producers under the prevailing environment. On the average, a farmer was able to make a net revenue of about $\$ 176,500.00$ with a BCR of $\$ 1.80$ in the farming season. This shows that cassava production is profitable. The result supports Gbigbi 's findings (2021) who stated a BCR of $\$ 2.38$ in Delta State.

\section{Determinants of Cassava Production}

The regression outcome revealed that $57 \%$ of the variability in production among the sample farmers was elucidated by the explanatory variables while the residual $43 \%$ could be contributed to error terms and omitted variables. The F-ratio was 21.180 and significant at $1 \%$ which implies that the explanatory variables jointly explained the dependent variable.

The result showed that farm size was positively correlated to output at $1 \%$ level. This suggests that a unit increase in farm size would lead to higher involvement in cassava production. The result validates the finding of Ibitoye and Onimisi (2013) who had a positive correlation between farm size and cassava output at $5 \%$ alpha.

The fertilizer utilized by the farmers was negative and significant at $1 \%$, suggesting an inverse association between fertilizer and output of cassava. This infers that increasing fertilizer will lead to reduced outputs. However, the statistical value indicates the contribution of fertilizers to the overall output of cassava. The continuing application of fertilizer on the farm will lead to soil acidity and the binding of certain significant micro and macro nutrients that are needed to optimize crop growth. This is in conformity with the a priori expectation. Any additional cost incurred will increase the overall production cost. Although fertilizer is required to improve soil fertility in its optimum level, its overuse is detrimental to soil. This result agreed with the outcomes of Odoemenem and Otanwa (2011) that fertilizer has had a negative 
relationship with cassava production in Benue State.

The variable labour was positively substantial at $5 \%$ alpha. This shows that an improvement in unit of labour would lead to an upsurge in output ceteris paribus. This is because increasing labour in cassava production adds additional output to decrease the total production costs and this increase farmers' returns. The finding is consistent with Obike et al. (2016), which states that labour was positively significant, implying that increased labour would result to higher farm turnover.

Planting material used by the farmers was positively correlated to output and significant at 5\%. This infers that increasing cassava stem leads to an increase in unit output. Again, statistical significance indicated that the use of cassava stem is associated with outputs of farmers. Thus, the a priori expectation was met. This finding is consistent with Yakasai (2010) on production of cassava in Abuja, Nigeria.

Table 3. Regression result of determinants of cassava production

\begin{tabular}{|l|l|l|l|l|}
\hline Variables & Coefficient & $\begin{array}{l}\text { Std. } \\
\text { Error }\end{array}$ & $\begin{array}{l}\text { t- } \\
\text { statistics }\end{array}$ & P- value \\
\hline Farm size & 5.3886 & 1.3763 & 3.92 & $0.000^{* * *}$ \\
\hline Fertilizer & -6.0140 & 1.5876 & -3.79 & $0.000^{* * *}$ \\
\hline Labour & 1.0392 & 0.3004 & 3.46 & $0.001^{* *}$ \\
\hline Agrochemical & 0.3681 & 0.2326 & -1.58 & 0.116 \\
\hline $\begin{array}{l}\text { Planting } \\
\text { material }\end{array}$ & 0.1520 & 0.0639 & 2.38 & $0.042^{* *}$ \\
\hline Constant & 0.9375 & 0.2531 & 3.70 & 0.000 \\
\hline \multicolumn{4}{|l|}{$* * * *, *$ significant at 1\% and 5\% respectively }
\end{tabular}

$\mathrm{R}^{2}=0.570$

Adjusted R squared $=0.543$

$\mathrm{F}-$ Ratio $=21.180$

\section{Elasticity of Production}

The elasticity of production measures the responsiveness of output to a change in input. Table 4 shows that 1\% increase in farm size, fertilizer used, labour and planting material would led to the $5.3886,-6.0140,1.0392,0.3681$ and 0.1520 percent increase cassava output. Moreover, the sum of elasticity is equal to 0.934 , implying that output increase by less than one percent if all inputs were increase by one percent. This suggests decreasing return to scale in cassava production. Hence, it pays to decrease the quantity of inputs used to optimize the amount of inputs used. The result is in accordance with Okoh (2016), which obtained decreasing returns to scale in Benue State.

Table 4. Elasticity of production and Return to scale

\begin{tabular}{|l|l|}
\hline Variable inputs & Input Elasticity \\
\hline Farm size & 5.3886 \\
\hline Fertilizer & -6.0140 \\
\hline Labour & 1.0392 \\
\hline Agro-chemical & 0.3681 \\
\hline Planting material & 0.1520 \\
\hline Return to scale & 0.934 \\
\hline
\end{tabular}

\section{Resource Use Efficiency in Cassava Production:}

The calculation of marginal value products (MVCs) and their corresponding marginal factors costs (MFCs) was based on the estimated coefficients of the respective independent variables. In the resource utilization ratio as shown in Table 5, the MVP to MFC ratio was used. Table 5 the result shows that the ratios for all variables are less than 1. This implies that an upsurge of each input would reduce the output value, indicating an overuse of all inputs. The overutilization of fertilizer was consistent with Adeyemo et al. (2010).

The overutilization of labour was necessitated by the use of labour-intensive technology as opposed to labour-saving equipment like the tractor. This result is consistent with Obasi et al.( 2013) studies in Imo State,Nigeria. The overutilization of agrochemicals results is consistent with resource-use efficiency studies conducted in Delta State (Eze and Nwibo, 2014). This suggests that farmers use resources inefficiently. The reasons could be because farm inputs are cheap and easily accessible. This means that cassava producers will increase their output by reducing their inputs level. This statement does not agree with Shehu (2007) study in Adamawa State in which land, seeds, hired labour, fertilizer and herbicides have been underused on rainfood and irrigated rice production. 
Theophilus Miebi Gbigbi et.al. Profitability and resource use efficiency in cassava production: evidence from Delta state, Nigeria.

Table 5. Analysis of resource use efficiency

\begin{tabular}{|l|l|l|l|l|l|l|}
\hline Variables & Coefficient & MPP & MVP & MFC & MFC/MVP & Efficiency \\
\hline Farm size & 5.388636 & 411.593 & 4115.93 & 9394.37 & 0.4381 & Over utilized \\
\hline Fertilizer & -6.013997 & 0.0451 & 0.451 & 2903.42 & 0.00016 & Over utilized \\
\hline Labour & 1.039169 & 7.2682 & 72.682 & 3125.64 & 0.0233 & Over utilized \\
\hline Agro-chemical & -0.368091 & 179.6077 & 1796.077 & 2024.44 & 0.8872 & Over utilized \\
\hline Planting material & -0.1519887 & 0.0133 & 0.133 & 909.4 & 0.00015 & Over utilized \\
\hline
\end{tabular}

Table 6 shows the percentage adjustment in marginal value products for optimum utilization of inputs. Optimum utilization of inputs requires that marginal value product be equal to inputs unit price, that is marginal factor cost (MVP = MFC). $56.19 \%$ adjustment is required for optimum utilization of farm size, $99.98 \%$ required for fertilizer, $97.67 \%$ required for labour and $99.99 \%$ for planting material. The result indicates that a lot need to be done to bridge the gap of optimum use of the resources in the area.

Table 6. Marginal value product (MVP) adjustment

\begin{tabular}{|l|c|}
\hline Variable inputs & Percentage adjustment required (\%) \\
\hline Farm size & 56.19 \\
\hline Fertilizer & 99.98 \\
\hline Labour & 97.67 \\
\hline Agro-chemical & 11.28 \\
\hline Planting material & 99.99 \\
\hline
\end{tabular}

\section{Constraints to Cassava Production}

Table 7. Constraints to cassava production
\begin{tabular}{|l|l|l|l|}
\hline Constraints & Frequency & Percentage & Rank \\
\hline Pest and diseases storage & 59 & 50.4 & $6^{\text {th }}$ \\
\hline $\begin{array}{l}\text { Inadequate } \\
\text { facilities }\end{array}$ & 53.0 & $5^{\text {th }}$ \\
\hline Poor market prices & 87 & 74.4 & $3^{\text {rd }}$ \\
\hline $\begin{array}{l}\text { Poor access to financial } \\
\text { services }\end{array}$ & 95 & 81.2 & $1^{\text {st }}$ \\
\hline High cost of Labour & 90 & 76.9 & $2^{\text {nd }}$ \\
\hline $\begin{array}{l}\text { Inadequate Extension } \\
\text { services }\end{array}$ & 80 & 68.4 & $4^{\text {th }}$ \\
\hline
\end{tabular}

The result disclosed that majority $81.2 \%$ of the producers experienced poor access to financial services as the major problem militating against the smooth operation of production while $76.9 \%$ were of the opinion that high labour cost was the major problem of production. More so, $74.4 \%$ and $68.4 \%$ of the producers identified poor market prices and inadequate extension services as the major constraint of production. Moreover, 53\% and 50.4\% of the growers were also of the view that inadequate storage facilities and pest and disease infestation were also among the identified problems affecting production (Table 7).

\section{CONCLUSION}

The findings show that farm size, fertilizer, labour, agrochemicals and planting materials by the producers was not effectively utilized. This implies that the inputs in the course of their production have been overused. Therefore, the increased production of cassava is affected negatively. This has far reaching implication for cassava production. Similarly, they are operating at decreasing return to scale; hence there is essential to expand the scope of their production by decreasing the usage of these inputs and achieve higher level resource-use efficiency. This requires a more effective and efficient extension service and easy access to loan facilities to increase the level of utilization by farmers and also enhance the establishment of cooperative societies to enable them to procure their inputs at reduced rates. In the end, they can help to expand the level of their revenue and output.

\section{Acknowledgement: None}

\section{Conflict of Interest: None}

\section{Source of Funding: None}

\section{REFERENCES}

1. Abdulkadir, M. B and Umar, A.S.S. Analysis of resource-use efficiency and productivity of residual soil moisture tomato production in Kaduna state, Nigeria. International Letters of Social and Humanistic Sciences, 2015; 51, 152-157.

2. Adebisi, A.O., Olajide, F.B., Adeoye, I.B. and Olajide, L.O.. Analysis of Production constraints Facing Fadama Vegetable Farmers in Oyo State. World J. Agric. Sci., 2012; 7(2): 189-192 
3. Adeyemo, R, Oke, J.T.O. ; Akinola, A.A. Economic Efficiency of Small Scale Farmers in Ogun State, Nigeria. Tropicultura; 2010; 28(2): 84-88.

4. Agwu A.E. and Anyaeche C.L.. Adoption of Improved Cassava Varieties in Six Rural Communities of Anambra State, Nigeria, African Journal of Biotechnology, 2007; 6(2): 89-98.

5. Alimi, T. Resource use efficiency in food crop production in Oyo State of Nigeria. Journal of Agriculture and Environment, 2000; 1 (1): 1-7.

6. Amaza, P. S., Abdoulaye, T., Kwaghe, P. and Tegbaru, A.. Changes in household food security and poverty status in PROSAB area of Southern; International Institute of Tropical Agriculture, Ibadan, Nigeria Borno State, and Nigeria.40pp. 2009.

7. Audu, S. I., Otitolaiye, J.O. and Ibitoye, S.J.. A Stochastic Frontier Approach to Measurement of Cost Efficiency in Small scale Cassava Production in Kogi State, Nigeria. European Scientific Journal, 2013; 9(9): $114-122$.

8. Ebewore, S.O, Ebodion, J. and Oboh, O.O.. Profitability analysis of yam production in Ika South LGA of Delta State, Nigeria. Journal of Biology, Agriculture and Healthcare, 2013; 3 (2):121.

9. Eze, A.V and Nwibo S.U.. Economic and technical efficiency of cassava production in Ika North East local government area of Delta State, Nigeria. Journal of Development and Agricultural Economics, 2014; 6(10):429-436.

10. Gbigbi, T.M .. Technical Efficiency and Profitability of Cassava Production in Delta State: A Stochastic Frontier Production Function Analysis. Journal of Tekirdag Agricultural Faculty, 2021; 18 (1), 21-31.

11. Gbigbi T. M . Measurement of profit efficiency among broiler producers in Delta State, Nigeria. African Journal of Agriculture, Technology and Environment, 2017; 6(2): 64-74.

12. Gbigbi, T.M .. Resource use efficiency and misery of sweet potato production window into financial surplus for households in Delta State Nigeria, International Journal of Agricultural Science, Research and Technology in Extension and Education Systems, 2019; 9(3):15-20.
13. Girei AA, Dire B. Profitability and technical efficiency among the beneficiary crop farmers of National Fadama II Project in Adamawa State, Nigeria. Net J. Agric. Sci. 2013; 1(3):87-92.

14. Goni, M., Umar, A.S.S. and Usman. S. Analysis of Resource-use Efficiency in Dry Season Vegetable Production in Jere, Borno State, Nigeria. Journal of Biology, Agriculture and Healthcare, 2013; 3(19): 18-23.

15. Ibitoye S. J and Onimisi J.A. Economic assessment of yam production in Kabba Bunu Local Government Area of Kogi State, Nigeria Global Journal of Agricultural Economics and Econometrics, 2013; 1(1):075-080.

16. Makinde Y.O, Balogun O.L, Bello, A..T and Afodu O.J. Technical Efficiency among Cassava Farmers in Ikenne Local Government Area of Ogun State, Nigeria. Ethiopian Journal of Environmental Studies and Management, 2015; 8(3): $342-350$.

17. Mango N, Clifton Makate C, HanyaniMlambo B, Siziba S and Lundy M. A stochastic frontier analysis of technical efficiency in smallholder maize production in Zimbabwe: The post-fast-track land reform outlook. Cogent Economics and Finance, 2015.;3: 1117189.

18. Nang'ayo, F., Odera, G., Muchiri, N., Ali, Z., and Werehire, P. N. A Strategy for Industrialization of Cassava in Africa.Proceedings of a Small Group Meeting, 14-28 November 2005, Ibadan, Nigeria. African Agricultural Technology Foundation, Kenya. 2007.http://aatfafrica.org/userfiles/CassavaProceedings.pdf.

19. Obasi, P.C., Henri-Ukoha, A., Ukewuike, S.I., and Chidiebere-Mark, N.M.. Factors Affecting Agricultural Productivity among Arable Crop Farmers in Imo State, Nigeria. American Journal of Experimental Agriculture, 2013; 3(2): 443 - 454.

20. Obayelu, A. E., Afolami, C. A., and Agbonlahor, M. U. Relative profitability of cassava-based mixed cropping systems among various production scale operators in Ogun and Oyo States Southwest Nigeria. African Development Review, 2013; 25, 513-525.

21. Obike, K.C., Idu, M.A. and Aigbokie, S.O. Labour Productivity and Resource Use Efficiency amongst Smallholder Cocoa Farmers in Abia State, Nigeria. Agro- 
Science Journal of Tropical Agriculture, Food, Environment and Extension, 2016; 15(3):7-12.

22. Odoemenem, I. U. and Otanwa, L. B. Economic Analysis of Cassava Production in Benue State, Nigeria. Current Research Journal of Social Sciences, 2011; 3(5): 406$411 .$.

23. Okoh, M.A. Analysis of profitability and resource use efficiency in cassava farming in Benue State of Nigeria. An M.Sc dissertation submitted to the Department of Agricultural Economics and Rural Sociology. Ahmadu Bello University Zaria; 2016.

24. Oyewole, S.O.. Analysis of Income Diversification Strategies and Food Security Status of Farmers in Oyo State of Nigeria. Unpublished M.Sc. Thesis, Department of Agricultural Economics and Rural Sociology, Ahmadu Bello University, Zaria, Nigeria; 2012.

25. Salau, S.A., Muhammad-Lawal, A. and Ajayi, S.A.. Economics of Improved and Local Varieties of Cassava Amongs Farmers in Oyo State, Nigeria. Ethiopian Journal of Environmental Studies and Management. 2012; 5(2): 189 - 194.

26. Shehu, J.F., Mshelia, S. I. and Tashikalma, A.K. Analysis of the Technical Efficiency of Small-scale Rainfed Upland Rice Farmers in the North West agricultural zone of Adamawa State. Journal of Agriculture and Social Sciences, 2007; 3(4):133 - 136.

27. Sugino, T. and Mayrowani, H. The determinants of cassava productivity and price under the farmers' collaboration with emerging cassava processors; 2009.

28. Tambo, J. A. and Theresa, G. Resource-use Efficiency in Tomato Production in the
Dargne west District Ghana. Paper presented on Conference on international Research on Food Security, National Resource Management and Rural Development; 2010.

29. Udemezue J. C, Chinaka E. C and Okoye B. C. .Cassava Value Chain as Instrument for Economic Growth and Food Security in Nigeria. Universal Journal of Agricultural Research, 2019; 7(6): 197-202.

30. Udo, E.J. Technical inefficiency in Vegetable Farms of Humid Region: An Analysis of Dry Season Farming by Urban Women in South-south Zone, Nigeria. Journal of Agriculture and Social Science, 2005; 1 (2):80-85.

31. Udoh, E. J. and N. A. Etim.. Measurement of Farm-Level Efficiency of Water-Leaf (Talinum triangulare) Production among City Farmers in Akwa Ibom State, Nigeria. Journal of Sustainable Development in Agriculture and Environment, 2008; $3(2): 47-54$.

32. Wasiu A, Adebayo B. A, Malu N, Bussie M.D. and Michael S. Assessment of the potential industrial applications of commercial dried cassava products in Nigeria. Food Measure, 2017; 11:598-609.

33. Yakasai, M. T. Economic Contribution of Cassava Production: A case study of Kuje Area Council, Federal Capital Territory, Abuja, Nigeria. Bayero Journal of Pure and Applied Sciences, 2010; 3(1): 215-219.

How to cite this article: Gbigbi TM, V.A.A. Chuks-Okonta. Profitability and resource use efficiency in cassava production: evidence from Delta state, Nigeria. International Journal of Research and Review. 2021; 8(6): 199-207. DOI: https://doi.org/10.52403/ijrr.20210624 